\title{
THE SURGICAL TREATMENT OF TARSO-METATARSAL FRAGTURE-DISLOGATIONS
}

\author{
Jose Manuel del Sel, Buenos Aires, Argentina
}

From the Department of Orthopaedic Surgery and Traumatology of the Faculty of Medicine of Buenos Aires*

Fracture-dislocation of the tarso-metatarsal joints-often called Lisfranc's fracturedislocation-is probably commoner than is generally supposed. In little over a year and a half I have encountered thirteen fresh cases, five of which had not been recognised on the first examination. The greatest incidence is among farm labourers and the mounted forces (Roca 1945). The injury usually results from a fall; the mechanism is a forced inversion or supination of the foot, a rotary movement that finds the weak point in the tarso-metatarsal joint, dislocating the metatarsals partly or completely from the cuneiforms or from the cuboid. The anatomical extent of the injury is variable; but in most cases the damage is greatest at the level of the first interosseous space, as though the violence were endeavouring to separate the first metatarsal from the remaining four.

There has been considerable divergence of opinion among surgeons on the best method of treating these injuries. In Argentina, Wybert and Perez Rovira (1944) favoured open reduction, and Comolli and Esteban (1947) reported successful results in three patients treated by internal fixation with metal plates. Gissane (1951) pointed out that Lisfranc's fracturedislocation, caused nearly always by a rotary strain on the forefoot, is always associated with some degree of arterial damage. The only other mention we have found of this complication is in a paper by Ferreyra and Arredondo (1940), who reported injury to the dorsalis pedis artery. In most descriptions (Quenu and Kuss 1909) attention is drawn to the almost constant separation between the first and second metatarsals with the tearing of the soft tissues that is to be expected. At this point the communication between the dorsalis pedis artery and the arch is torn. Gissane considered that the arterial injury does not endanger the life of the foot unless the posterior tibial or the lateral plantar artery should also be damaged. He mentioned three cases of severe arterial damage which culminated in amputation. Even in cases with only slight displacement he favoured open reduction, believing that a better functional foot was ensured by repair of the soft tissues and accurate reposition of the bones.

After returning from England in 1951 I had the opportunity to treat a patient with this injury according to the new ideas I had formed - that is, by open reduction but with internal fixation by temporary percutaneous wire transfixion, thus avoiding the use of screws, plates or non-absorbable suture material. Since then I have treated a further twelve patients with similar injuries, though not all with severe displacement. Of the total of thirteen cases three were treated by closed reduction, two by physiotherapy alone, and eight by operative reduction.

\section{TEGHNIQUE OF OPERATION}

With the limb exsanguinated by a tourniquet a dorsal incision is made in the first interosseous space. Blood clot is cleared out and the termination of the dorsalis pedis artery is inspected. In nearly all the cases there was not found the communication between the dorsalis pedis artery and the plantar arch. The haematoma varied considerably from one case to another. In no instance did we find the artery severed and bleeding. After clearance of bone fragments, bits of cartilage or soft tissue from the first interosseous space, the jagged ends of the tarsal bones and the metatarsals are reduced. Usually by levering the second

* Director, Professor José Valls. 
metatarsal and supinating the foot a good reduction can be obtained and maintained. In some cases a second incision is necessary to reduce the third or fourth metatarsal.

Fixation is secured by transfixion with wire pins, inserted with a pneumatic or electric drill; the number of wires needed varies from one to four. The wires are included in the plaster and retained for two to four weeks. After they have been withdrawn the patient is encouraged to walk with a below-knee plaster.

\section{RESULTS}

The results of operative reduction were good in all cases. There were no complications and the wires produced no ill-effect. In no instance did redisplacement occur. There was no

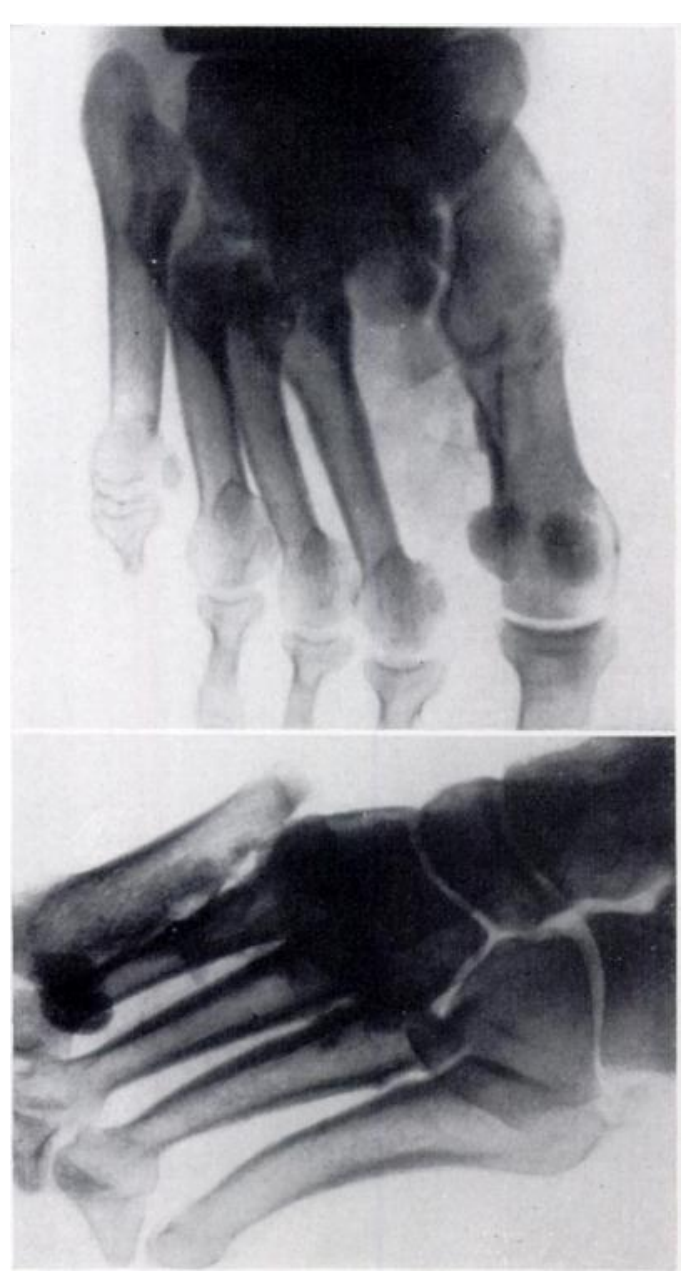

FIG. 1

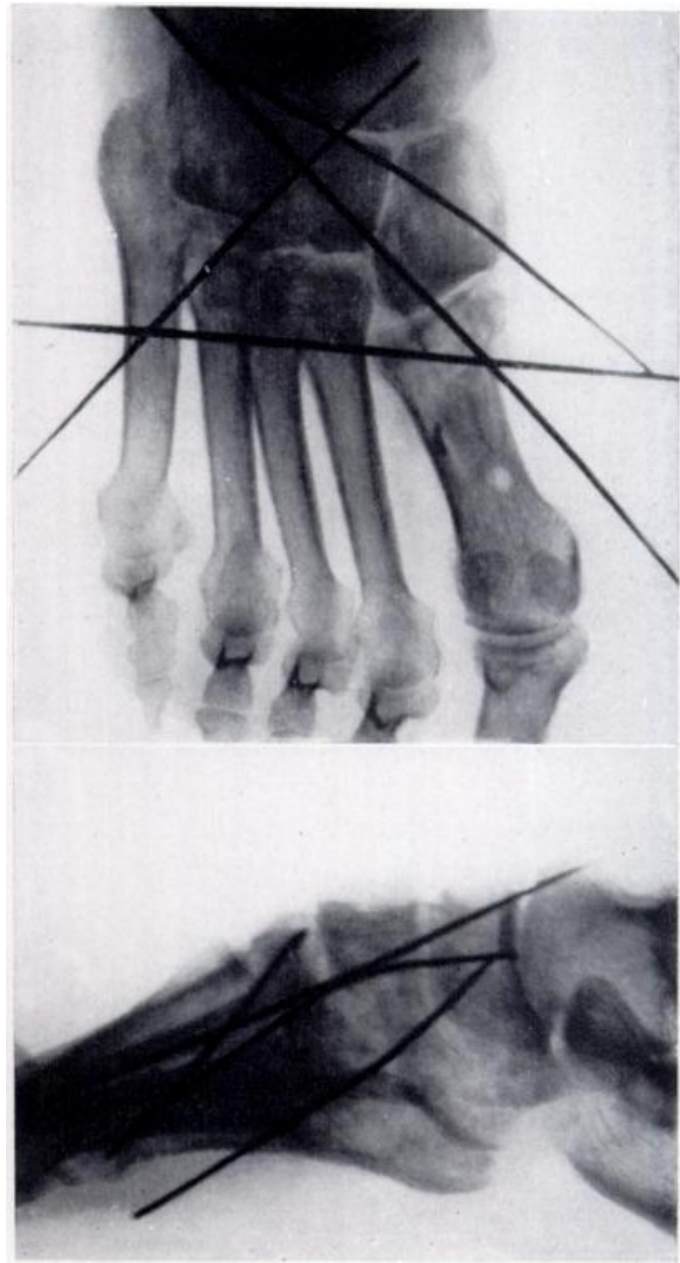

FIG. 2

Case 2. Figure 1-Before reduction. Figure 2-After operative reduction and fixation by wires.

vascular disturbance except in one case in which a certain amount of infiltration remained, with slight subcutaneous oedema. In no case was arthrodesis required, but the erasing of the tarso-metatarsal line was evident in the radiographs after a few months.

\section{CASE REPORTS}

Case 1-A labourer aged twenty sustained a Lisfranc's fracture-dislocation when a horse stamped on his left foot. 1)uring operative reduction it was necessary to excise a small piece of the second 
metatarsal before accurate replacement could be obtained. One transfixion wire was used to prevent redisplacement. Progress was good and he was discharged fit for work three and a half months after the injury.

Case 2-A stevedore aged fifty-five suffered injuries, including a I.isfranc's fracture-dislocation when he fell twenty feet (Fig. 1). Closed reduction was attempted but was only partly successful. Open reduction was undertaken two weeks after the injury. It was necessary to expose both the first and fourth interosseous space, and a piece of the second metatarsal that was impeding reduction had to be excised. The position was maintained by four transfixion wires incorporated in the plaster (Fig. 2). The foot remained slightly swollen but the result was good.

Case 3-A clerk aged forty-four fell six feet, twisting his right foot. There was severe displacement (Fig. 3). Immediate closed reduction was attempted without success. Open reduction was carried out and the bones were secured by two transfixion wires (Fig. 4). The result was satisfactory.

Case 4 - A woman fell down some steps, twisting the left foot and causing a Lisfranc's fracturedislocation. Several attempts at closed reduction were unsuccessful. A good result followed operative reduction by the method described.

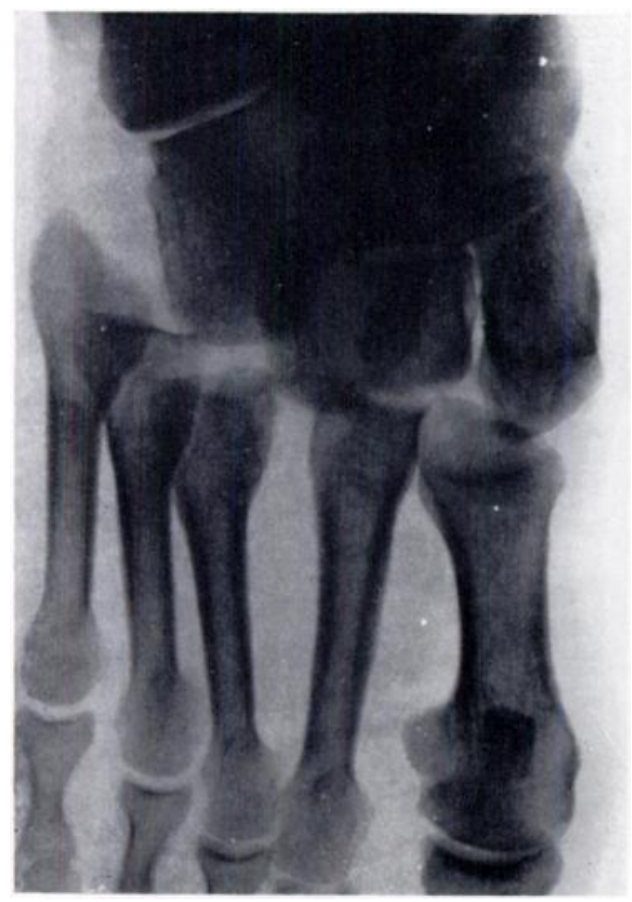

Fig. 3

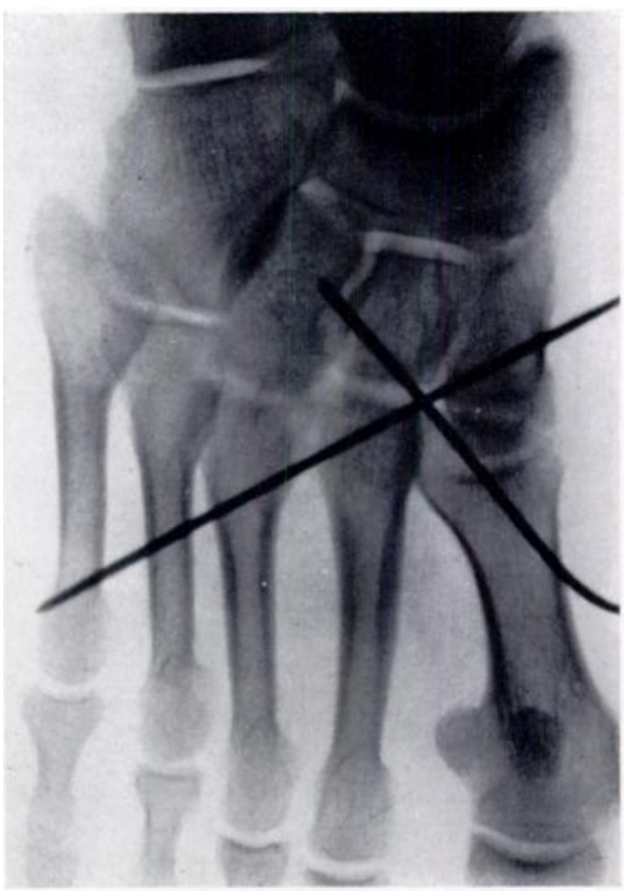

FIG. 4

Case 3. Figure 3-Before reduction. Figure 4-After operative reduction, showing the temporary transfixion wires in position.

Case 5 -A labourer aged forty had his right foot crushed by a cart. Open reduction was performed and the position was held by a transfixion pin through the second metatarsal and first cuneiform which was also fractured. The result was good.

Case 6-A woman aged thirty-five was injured when a log of wood fell across her left foot. There was marked deformity (Fig. 5). After open reduction the position was maintained by two transfixion wires incorporated in the plaster for two months (Fig. 6). Progress was satisfactory.

Case 7 - $A$ man aged twenty-eight slipped from a bus, twisting his right foot. There was minor displacement of the first and second metatarsals. They were levered back into position through an incision exposing the interosseous space, and reduction was maintained by one transfixion wire and plaster. A good result was obtained.

Case 8-A man aged thirty-eight sustained a compound fracture-dislocation of the first tarsometatarsal joint when a sheet of iron fell upon his left foot (Fig. 7). There was an extensive laceration

vol. $37 \mathrm{~B}$, No. 2 , MAY 1955 
at the medial border of the foot and the medial plantar artery was torn. At immediate operation all damaged soft tissue was excised and the dislocation was reduced. The position was held by a transfixion wire, the wound being only partly closed (Fig. 8). Four weeks later the wire was withdrawn and the wound closed by skin-grafting. A perfect anatomical and functional result was obtained.

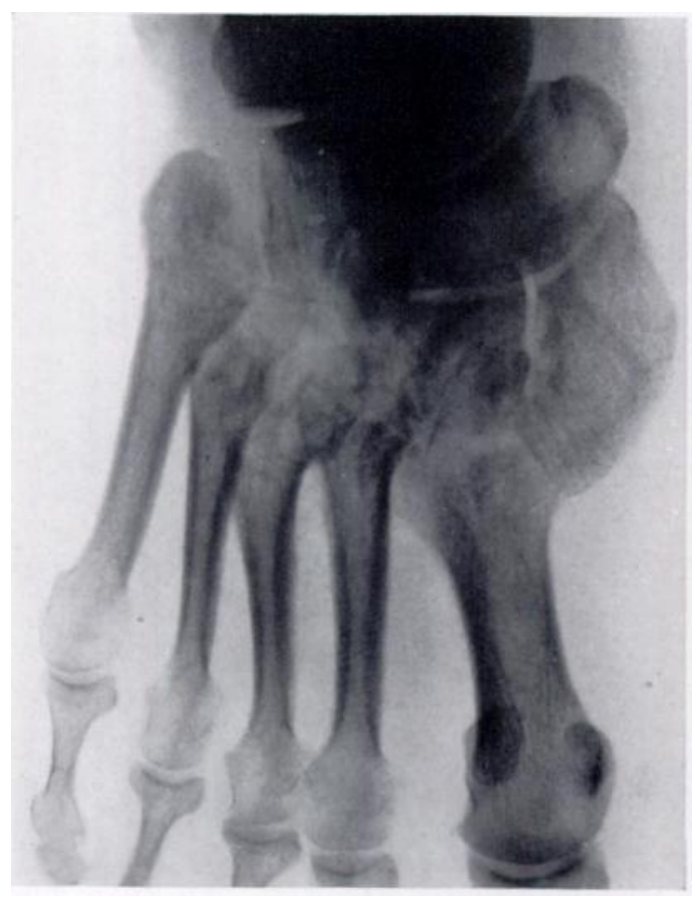

FIG. 5

Case 6. Figure 5 - Before reduction.

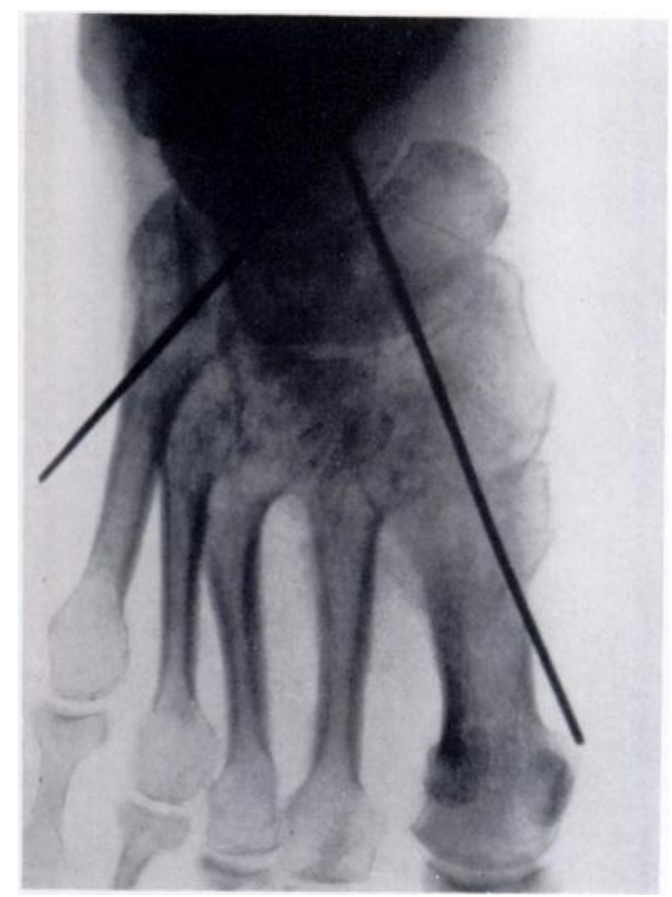

FIG. 6

Figure 6-After operative reduction.

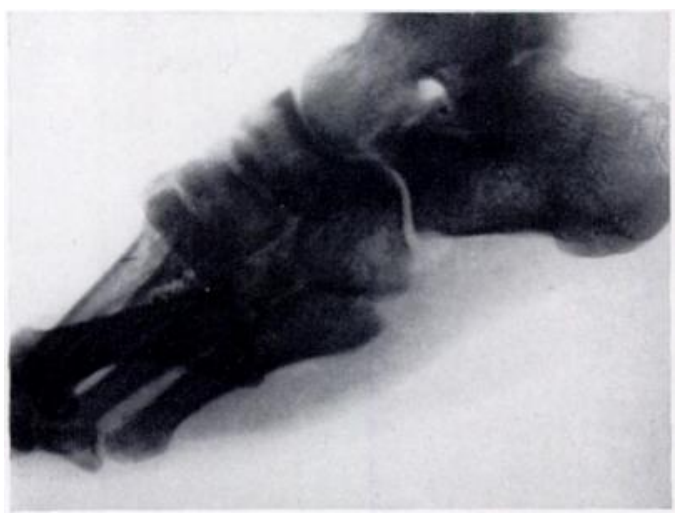

Fig. 7

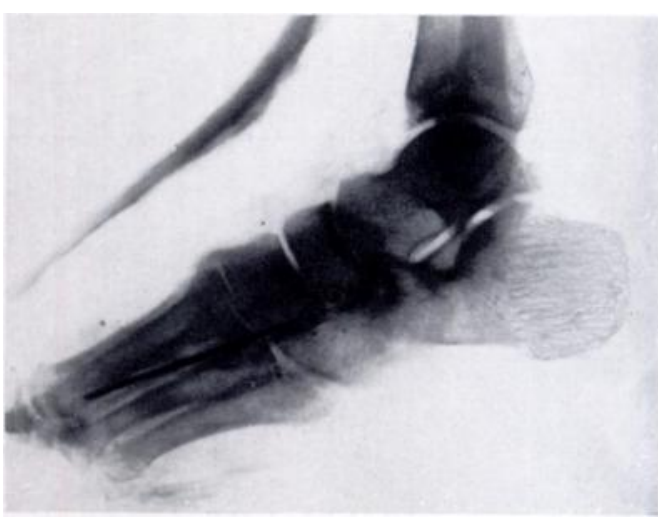

Fig. 8

Case 8. Figure 7-Before reduction; marked displacement of base of first metatarsal. Figure 8-After operative reduction, with transfixion wire in position.

\section{GOMMENT}

The possibility of vascular lesions should always be borne in mind, but the risk is probably not serious when the lateral plantar artery is intact. To reduce the risk of vascular impairment reduction should be carried out as soon as possible.

The method that I have described ensures excellent fixation without the use of any internal metal that might require removal later. 


\section{SUMMARY}

1. In the treatment of tarso-metatarsal fracture-dislocations open reduction is advocated whenever closed reduction is found impossible.

2. A technique of operation is described whereby, after reduction, temporary transfixion wires are used to prevent redisplacement.

\section{REFERENCES}

Comolli, E. P., and Esteban, H. V. (1947): Pié; Luxación-fractura de la articulación de Lisfranc. Tratamiento quirúrgico. Boletines y trabajos de la Sociedad argentina de cirugia ortopédica, 12, 38.

Ferreyra, J. A., and Arrendondo, F. O. (1940): Luxación de la articulación de Lisfranc. Boletines y trabajos de la Sociedad argentina de cirujanos, 1, 687.

Gissane, W. (1951): A Dangerous Type of Fracture of the Foot. Journal of Bone and Joint Surgery, 33-B, 535.

Qứxu, E., and Küss, G. (1909): Étude sur les Luxations du Métatarse. Revue de Chirurgie, 39, 1; $281 ; 720 ; 1,093$.

RocA, C. A. (1945) : A Propósito de luxo-fractura de la articulación de Lisfranc. Boletines y trabajos de la Sociedad argentina de cirujanos, 6, 61 .

Wybert, A., and Perez Rovira, J. A. (1944): Luxo-fractura de la articulación de Lisfranc. Boletines y trabajos de la socieded argentina de cirujanos, 5, 1,260. 